\section{Polarographic Estimation of Vitamin C}

AQUEous solutions of vitamin $\mathrm{C}$ when electrolysed at the dropping mercury cathode do not produce any effect on the current-voltage curves. If, however, to a solution of vitamin $\mathrm{C}$ - freed from air-a mild oxidizing agent, such as cupric chloride, silver nitrate, gold chloride, ferric chloride or iodine is added, a polarographic 'wave' appears on the current-voltage curve at $-1 \cdot 60 \mathrm{v}$. (from the calomel zero). This 'wave' has been shown to be due to the deposition of free hydrions liberated in the solution by the reaction :

$$
\text { ascorbic acid }
$$

This polarographic effect is not specific for vitamin C, as it may be also caused by the presence of other oxidizable compounds like glutathione or cysteine. It is remarkable that the oxidized form of vitamin C, namely, the dehydroascorbic acid, is not electro-reducible at the dropping mercury cathode. It probably changes irreversibly into a hydrated form.

However, a characteristic polarographic effect of vitamin $\mathrm{C}$ is obtained, when the dropping mercury electrode is polarized as anode. Then a polarographic 'wave' appears at about $+0.3 \mathrm{v}$. from the potential of a reversible hydrogen electrode and is shifted according to the $p \mathrm{H}$ of the solution. For practical purposes it is best to keep the solution at $p \mathrm{H} 7$ in an N/15 phosphate buffer solution, in which the anodic effect of chloride ions or of glutathione does not interfere with the position of the polarographic 'wave' of ascorbic acid (see the accompanying graph).

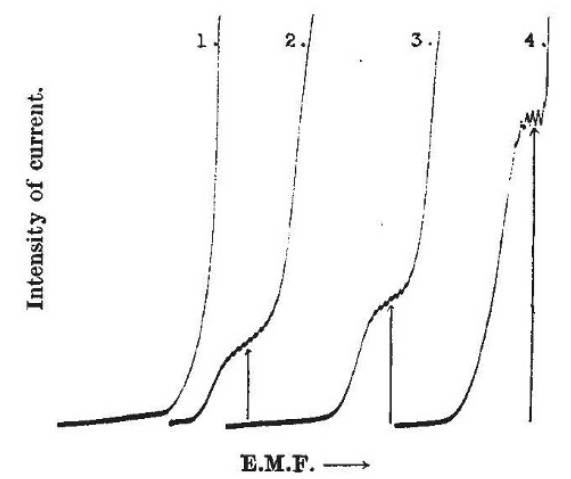

ANOdic 'WAVhs' DUE TO VITAMTN C.

Curve 1: Pure N/15 phosphate buffer $p \mathrm{H} 7$. CURves 2 and 3 : 0.5 AND 1.0 c.c. ORANGE JUICE ADDED TO 4 c.c. BUFFer SOlution. CURVE $4: 0.5$ c.c. OF $0.01 M$ ASCORBIC ACID ADDED TO 4 c.c. BUFFER SOLUTION.

Sensitivity OF THE GaLVANOMETER $10^{-7}$ AMP./MM., 1 CM. OF ABSCISSA $=0.2$ vOLT.

We have ascertained that vitamin $\mathrm{C}$ may be estimated with the usual polarographic sensitivity and accuracy, like hydroquinone ${ }^{1}$, that is, down to concentrations of $10^{-5}$ molar, which means $1 \gamma$ of vitamin $\mathrm{C}$ in the 1 e.c. necessary to carry out the analysis.
As vitamin $\mathrm{C}$ is polarographically active only in the reduced form, the analysis should be carried out in absence of air. For that purpose, $0 \cdot 5-1$ c.c. of the fresh lemon or orange juice is added to 4 c.c. of the phosphate buffer $(p \mathrm{H} 7)$ freed from atmospheric oxygen. If the polarographic curve is recorded shortly after mixing, good results are obtained even in the presence of air.

Extractions from animal tissues, however, offer difficulties, inasmuch as other constituents seem to hinder the electrode reaction.

Full details of this investigation will be published elsewhere.

Department of Zoology and E. KoDfčEK.

IInd Internal Clinic,

K. WENIG.

Charles University,

Prague. May 22.

' Müller, O. H., and Baumberger, J. P., Trans. Electrochem. Soc., 71, 169 (1937).

\section{Biological Assay of Vitamin E}

THE recent communication from Karrer et al. ${ }^{1}$ makes it inevitable that comparisons will soon be needed between the biological activities of various substances having the properties of the 'anti-sterility' vitamin. In particular, interest is likely to centre round the relative potencies of the various tocopherols and of synthetic substances. The preparation in these laboratories of a curve relating dosage and response to vitamin $\mathrm{E}^{2}$ has enabled us to interpret the results obtained with specimens of highly purified tocopherol allophanates, and so to contribute some evidence as to the relative activities of the $\alpha$ - and $\beta$-forms, a matter on which the literature contains rather indefinite reports.

In accordance with our practice, we have compared the mean fertility doses of the substances-that is, the doses that will cause 50 per cent of implanted animals to bear live litters. During the test, all conditions are kept as uniform as possible, virgin animals only being used and the doses being divided into ten equal portions and administered every day for the ten days following positive mating. The table below summarizes the results so obtained; the figures for the mean fertility doses refer to weights of tocopherol, calculated from the weights of the allophanates, which were carefully hydrolysed and

\begin{tabular}{|c|c|c|c|}
\hline Substance & M.P. & $\begin{array}{l}\text { No. of animals } \\
\text { used }\end{array}$ & $\begin{array}{l}\text { Mean fertility } \\
\text { dose }\end{array}$ \\
\hline $\begin{array}{l}\alpha \text {-tocopherol } \\
\beta \text {-tocopherol }\end{array}$ & $\begin{array}{l}160^{\circ} \mathrm{C} . \\
142-3^{\circ} \mathrm{C} .\end{array}$ & $\begin{array}{l}* 9 \\
+6\end{array}$ & $\begin{array}{l}1.2 \mathrm{mgm} \text {. (weighted) } \\
1.9 \mathrm{mgm} \text {. }\end{array}$ \\
\hline
\end{tabular}
dissolved in cod liver oil for feeding to the test animals.

* At two different dose levels : a still higher dose gave 100 per cent fertility.

+ At one dose level: tests at several lower doses gave almost complete sterility.

The specimens of tocopherol were both derived from wheat germ oil concentrates. The highly purified allophanates were prepared by Dr. A. R. Todd, for whose assistance we are very grateful, from crude allophanates supplied by Dr. B. K. Blount, of the Chemical Research Department in these laboratories.

\section{Glaxo Laboratories, Ltd.,} Greenford,

Middlesex. June 16.

${ }^{1}$ Karrer, P., Fritzsche, H., Ringier, B. H., and Salomon, H., NatuRe, 141, 1057 (1938).

${ }^{2}$ Bacharach, A. L., Allchorne, E., Chem. and Ind., 57, 600 (1938). 